\title{
PENERAPAN METODE PROBLEM SOLVING UNTUK MENINGKATKAN KEMAMPUAN BERPIKIR KRITIS PESERTA DIDIK
}

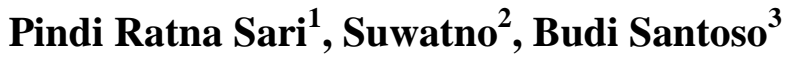 \\ Universitas Pendidikan Indonesia ${ }^{1,2,3}$ \\ Email: pindi.ratnasari11@gmail.com,suwatno@upi.edu,budisantoso@upi.edu
}

\begin{abstract}
ABSTRAK
Tujuan penelitian ini adalah untuk mengetahui peningkatan kemampuan berpikir kritis peserta didik dengan menggunakan metode problem solving.Metode yang digunakan peneliti adalah metode penelitian kuasi eksperimen dengan kuantitatif, yaitu dengan memberi dua perlakuan berbeda terhadap dua kelompok siswa.Kelompok pertama diberikan sistem pembelajaran melalui metode problem solving sebagai kelas eksperimen, sedangkan kelompok kedua mendapat pembelajaran dengan metode konvensional sebagai kelas kontrol.Penelitian ini di lakukan di kelas X IPS 2 dan X IPS 4 di SMAN 2 Lembang. Berdasarkan hasil penelitin ini menujukkan bahwa terdapat peningkatan kemampuan berpikir kritis siswa kelas eksperimen dibanding siswa kelas kontrol dalam menanggapi materi yang disampaikan dengan menggunakan metode problem solving hal ini dapat dilihat dari nilai posttest kelas eksperimen tertinggi yaitu 90 sedangkan nilai postest kelas kontrol tertinggi yaitu 80. Pengujian Hipotesis (Uji-t) postest dapat dilihat bahwa nilai probabilitas signifikan atau p-valuenya adalah 0,008 atau lebih kecil dari 0,05 atau 5\% yang artinya metode problem solving berpengaruh terhadap kemampuan berpikir kritis peserta didikdi SMAN 2 Lembang pada kelas X IPS2 pada mata pelajaran ekonomi.
\end{abstract}

Kata Kunci: Problem Solving dan Berpikir Kritis

\section{ABSTRACT}

The purpose of this study is to study the improvement of students' thinking by using problem solving methods. The method used by researchers is a quasiexperimental research method with quantitative, by providing different assistance to two groups of students. The first group provides a learning system through problem solving methods as an experimental class, while the second group learns by conventional methods as a control class. This research was conducted in class X IPS 2 and X IPS 4 in SMAN 2 Lembang. Based on the results of this research shows what is meant by an increase in the ability to think critically the experimental class of students controlling the material presented using the problem solving method this can be seen from the post-test scores of the experimental class increased by 90 while the post-test scores reached 80. The posttest (t-test) hypothesis can be seen because the significant probability value or p-value is 0.008 or smaller than 0.05 or $5 \%$, which means the problem solving method for the critical thinking skills of students in SMAN 2 Lembang in class X IPS 2 in economic subjects.

Keywords: Problem Solving and Critical Thinking

Jurnal Edueksos Vol. IX, No. 1, Juni 2020

The journal of social and economics education 


\section{A. PENDAHULUAN}

Pendidikan merupakan salah satu pilar utama dalam menentukan perubahan sosial. Perubahan ke arah kemajuan dan kesejahteraan hidup yang berkualitas. Menurut Undang-Undang Sistem Pendidikan Nasional (Sisdiknas) No.20 Tahun 2003. Seiring dengan berkembangnya ilmu pengetahuan dan teknologi yang pesat di era globalisasi ini, ternyata membawa pengaruh yang cukup signifikan dalam dunia pendidikan. Berbagai upaya untuk meningkatkan kualitas pendidikan terus dilakukan, seperti pembaharuan kurikulum dan peningkatan mutu pembelajaran disekolah. Salah satunya dengan mengembangkan berbagai metode pembelajaran dan mengembangkan potensi siswa untuk memajukan pendidikan.

Pemilihan strategi, pendekatan, metode serta model pembelajaran mempunyai andil yang cukup besar dalam kegiatan belajar mengajar. Namun dalam penerapannya, perlu disadari bahwa tidak setiap metode dan pedekatan sesuai dengan materi yang diajarkan. Metode pembelajaran disekolah padaumumnya masih menunjukkan bahwa guru masih belum optimal dalam proses pembelajaran. Sehingga diperlukan pelaksanaan pembelajaran yang mengacu pada peningkatan kualitas aspek-aspek pembelajaran terutama dalam kempuan siswa untuk berpikir kritis yang dapat meningkatkan kualiatas peserta didik (Rohaumah, 2018).

Berpikir kritis adalah suatu cara yang dilakukan seseorang secara sadar atas pengetahuan yang dimilikinya untuk menemukan apa yang di analisanya. Berpikir kritis juga sebagai proses kegiatan mengambil keputusan dalam memecahkan masalah secara terarah dan terorganisasi dengan baik sehingga menghasilkan pemecahan masalah dengan tepat. Hal ini berarti berpikir kritis merupakan pemikiran yang menggunakan pertimbangan yang aktif, terus menerus dan cermat terhadap informasi dan keyakinan dengan mempertimbangkan buktibukti yang mendukung untuk mempercayai atau melakukan sesuatu (Rahmawanty, 2017). Jika seseorang yang memiliki kemampuan berpikir kritis akan mampu memecahkan masalah secara efektif. Kalimat ini menjelaskan bahwasannya berpikir kritis sangat penting bagi kehidupan, dimana kehidupan penuh dengan permasalahan, terutama di abad 21(Peter, 2012). Kareana kehidupan yang semakin 
kompleks di abad 21 menuntut setiap orang untuk memiliki kemampuan berpikir kritis. Kompleksnya permasalahan hidup yang terjadi menuntut seseorang untuk berani dan tegas dalam mengambil keputusan yang benar (Wijayanti, 2016).

Berpikir kritis adalah sikap yang diasah dan dipelajari. Aspek yang penting yang mempengaruhi proses berpikir kritis misalnya seperti disiplin. Seseorang yang berpikir kritis akan dapat menjawab permasalahan-permasalahan yang penting dengan baik. Berpikir kritis merupakan suatu keterampilan yang menggunakan pengetahuan dan intelegensi untuk mendapatkan objektivitas dan pandangan yang dapat diterima secara akal. Salah satu tujuan utama pembelajaran ialah meningkatkan kemampuan siswa berpikirkritis, agar dapat mengambil keputusan rasional tentang apa yang harus dilakukan atau apa yang harus diyakini (Prayitno et al., 2016). Berpikir kritis merupakan potensi yang dimiliki oleh setiap orang, dapat di ukur, dilatih, dan dikembangkan (Lambertus, 2009). Berpikir kritis adalah kemampuan intelektual yang memungkinkan seseorang untuk terampil dan aktif dalam hal pemahaman, pengaplikasian, pensitesisan, serta pengevaluasian bermacam-macam informasi yang diakumulasikan dari berbagai pengamatan, refleksi, penalaran, komunikasi dan pengalaman yang dialaminya. (Liberna, 2012).

Adapun berpikir kritis juga memiliki beberapa karakteristik.berpikir kritis itu memiliki empat karakteristik, yakni: 1. Bertujuan untuk mencapai penilaian yang kritis terhadap apa yang akan kita terima atau apa yang akan kita lakukan dengan alasan logis. 2. Memakai standar penilaian sebagai hasil dari berpikir kritis dan membuat keputusan. 3. Menerapkan berbagai strategi yang tersusun dan memberikan alasan untuk menentukan dan menerapkan standar. 4. Mencari dan menghimpun informasi yang dapat dipercaya untuk dipakai sebagai bukti yang mendukung suatu penilaian (Mustaji, 2012).

Setiap orang memiliki kemampuan berpikir yang berbeda. Terdapat faktorfaktor yang mempengaruhi kemampuan berpikir kritis seseorang yaitu: (1) kondisi fisik, (2) keyakinan diri/motivasi, (3) kecemasan, (4) kebiasaan dan rutinitas, (5) perkembangan intelektual, (6) konsistensi, (7) Perasaan, (8) pengalaman (Maryam, 2008).

Seseorang dikatakan berpikir kritis dapat dilihat dari beberapa indikator. Membagi indikator keterampilan berpikir kritis menjadi lima kelompok, yaitu: (1) 
memberikan penjelasan sederhana (elementaray clarification), (2) membangun keterampilan dasar (basic support), (3) membuat kesimpulan sementara/inferensi (inferring), (4) membuat penjelasan lebih lanjut (advanced clarification), (5) mengatur strategi dan taktik (strategies andtactics) (Komalasari, 2011).

Berdasarkan dari beberapa definisi di atas dapat disimpulkan bahwa kemampuan berpikir kritis merupakan kemampuan yang sangat penting bagi setiap orang, yang digunakan untuk memecahkan masalah dengan berpikir serius, aktif, teliti dalam menganalisis semua informasi yang mereka terima dengan menyertakan alasan yang rasional sehingga setiap permasalahan dapat dijawab dengan tepat dan tindakan yang akan dilakukan adalah benar.

Berdasarkan wawancara guru mata pelajaran ekonomi yang dilakukan di SMAN 2 Lembang di peroleh informasi bahwa mata pelajaran ekonomi di bilang masih rendah karena beberapa siswa masih ada yang di bawahkriteria ketuntasan minimal (KKM) yang telah ditetapkan hanya sekitar 37\% yang sama atau di atas KKM pada pelajaran ekonomi. Hal ini dapat dilihat dari hasil ujian akhir semester peserta didik dimana kelas X IPS 2 dengan jumlah siswa 36 terdapat 8 siswa mendapat nilai di atas KKM dan 28 siswa yang mendapat nilai di bawah KKM, sedangkan untuk kelas X IIS 4 dengan jumlah siswa 36 terdapat 5 siswa yang mendapat nilai di atas KKM dan 31 siswa mendapat nilai di bawah KKM. Sehingga dari data tersebut dapat disimpulkan bahwa sebagian besar siswa masih memiliki keterampilan berpikir kritis cukup rendah, dikarenakan guru masih menggunakan metode ceramah sehingga siswa tidak terpacuuntuk menemukan sendiri atau mencari informasi mengenai materi kajian pelajaran yang sedang dipelajari yangdapat lebih meningkatkan kemampuan berpikir kritis siswa.

Untuk memecahkan masalah pembelajaran tersebut perlu dilakukan upaya antara lain berupa perbaikan strategi pembelajaranyaitumetodepembelajaran yang diharapkan mempermudah peserta didikdalam berpikir kritis dan ketrampilan memecahkan masalah sehingga tercapai hasil yang lebih maksimal. Salah satu metode pembelajaran yang digunakan adalah pembelajaran berbasis pemecahan masalah (U. Setyorini, S.E. Sukiswo, 2011).

Peneliti memilih menggunakan metode pembelajaran Problem Solving karena metode Problem Solving dapat melatih dan membiasakan peserta didik untuk 
menghadapi dan memecahkan masalah secara terampil Penggunaan metode pembelajaran ini dapat digunakan secara optimal dalam proses pembelajaran untuk melatih keterampilan berpikir kritis peserta didik. Problem Solving merupakan pembelajaran berbasis masalah, yakni pembelajaran yang berorientasi "learner centered" dan berpusat pada pemecahan suatu masalah oleh peserta didik melalui kerja kelompok (Majid, 2015).

Problem solving merupakan cara dalam memecahkan masalah yang didahului dengan cara menstimulasi dan memberikan pengertian agar siswa memperhatikan, berpikir dan menelaah suatu masalah tersebut. Pendapat tersebut memberikan gambaran bahwa dengan beberapa tahap yang harus dilalui dalam proses pemecahan masalah melibatkan unsur-unsur kognitif seperti memperhatikan, menelaah, menganalisis, dan mengevaluasi, sehingga siswa akan terlatih mengembangkan kemampuan berpikir kritisnya (Tijayanti, 2014). Problem Solving adalah suatu pembelajaran yang melakukan pemusatan pada pengajaran dan keterampilan pemecahan masalah yang diikuti dengan penguatan keterampilan. Jadi, masalah dapat didefinisikan sebagai suatu persoalan yang tidak rutin dan belum dikenal cara penyelesaiannya. Problem Solving adalah mencari atau menemukan cara penyelesaian (menemukan pola atau aturan) (Shoimin, 2014).

Karakteristik pemecahan masalah 1). Terjadi interaksi antara peserta didik dengan peserta didik, dan interaksi pendidik dengan peserta didik. 2). Adanya dialog matematis dan konsesus antar peserta didik. 3). Pendidik menjelaskan latar belakang atau maksud dari masalah, dan peserta didik mengklarifikasi, menafsirkan, dan berusaha untuk membangun satu atau lebih proses solusi. 4). Pendidik menerima jawaban benar atau salah dalam caranonevaluative (tanpa mengevaluasi). 5). Pendidik membimbing melatih dan mengajukan pertanyaan dan berbagi wawasan dalam proses pemecahan masalah. 6). Pendidik mengetahui kapan saat yang tepat untuk campur tangan dan kapan harus melangkah mundur dan membiarkan peserta didik membuat jalan mereka sendiri.7). Problem solving dapat digunakan untuk mendorong peserta didik untuk membuat generalisasi aturan dan konsep, sebuah proses yang memusatkan dalam pembelajaran (Permatasari, 2012).

Ada tiga prinsip yang ada pada Problem Solving, yaitu: 1. Problem Solving merupakan keterampilan yang biasa dipelajari dan bukan merupakan bakat yang 
hanya dimiliki oleh sebagian orang saja. 2. Problem Solving merupakan kerangka berpikir yang sistematis dan utuh untuk mendapatkan solusi. 3. Problem Solving merupakan kombinasi antara berpikir dan bertindak (Iskandar, 2017).

Pemecahan masalah dipandang sebagai suatu proses untuk menemukan kombinasi aturan yang dapat diterapkan dalam upaya mengatasi situasi baru. Jadi dengan menerapkan pembelajaran Problem Solving peserta didik diharapkan telah mengetahui teori-teori yang dipelajari, kemudian dapat digunakan untuk memecahkan masalah (Wena, 2011).

Adapun langkah-langkah dalam penggunaan metode Problem Solving sebagai berikut: 1. Masalah sudah ada dan materi diberikan. 2. Peserta didik diberi masalah sebagai pemecahan/diskusi, kerja kelompok. 3. Masalah tidak dicari (sebagaimana pada problem based learning dari kehidupan mereka sehari-hari).4. Peserta didik ditugaskan mengevaluasi (evaluating) dan bukan grapping seperti pada problem based learning. 5. Peserta didik memberikan kesimpulan dari jawaban yang diberikan sebagai hasil akhir. 6. Penerapan pemecahan masalah terhadap masalah yang dihadapi sekaligus berlaku sebagai pengujian kebenaran pemecahan tersebut untuk dapat sampai kepada kesimpulan (Shoimin, 2014).

Dari berbagai pendapat di atas dapat disimpulkan mengenai metode problem solving atau sering disebut dengan metode pemecahan masalah merupakan suatu metode atau cara mengajar guru yang merangsang peserta didik untuk menganalisis suatu masalah dengan logis, kritis, dan mandiri sehingga dapat menarik kesimpulan dengan baik dari masalah tersebut.

Berdasarkan latar belakang diatas, maka masalah yang dikaji dalam penelitian ini adalah apakah penerapan metode Problem Solving dapat meningkatkan kemampuan berpikir kritis peserta didik. Tujuan penelitian ini adalah untuk mengetahui peningkatan kemampuan berpikir kritis peserta didik sebelum dan sesudah mengggunakan metode pembelajaran Problem solving.

\section{B. METODE PENELITIAN}

Penelitian ini menggunkan metode quasi eksperimen, yaitu dengan memberi dua perlakuan berbeda terhadap dua kelompok siswa. Kelompok pertama diberikan sistem pembelajaran melalui metode problem solving sebagai kelas eksperimen, sedangkan kelompok kedua mendapat pembelajaran dengan 
metode konvensional sebagai kelas kontrol.Penelitian dilakukan pada kelas X IPS 2dengan menggunakan metode problem solvingdan X IPS 4 menggunakan metode konvensioal di SMA Negeri 2 Lembang yang masing-masing kelas berjumlah 36 siswa. Penelitian ini digunakan instrumen tes yang terdiri dari seperangkat soal pilihan ganda untuk mengukur dan mengetahui kemampuan berpikir kritis peserta didik dengan materi bank sentral. Analisis data menggunakan uji validitas, uji reliabiitas, tingkat kesukaran dan daya pembeda sedangkan untuk teknik alasisis data menggunakan uji normalitas, ujihomogenitas dan uji hipotesis dengan menggunakan program SPSS 21 for windows.

Variabel dalam penelitian ini terdiri dari dua variabel yaitu satu variabel bebas (independent variable) dan satu variabel terikat (dependent variable).Variabel bebas dalam penelitian ini yaitu metode problem solving, sedangkan variabel terikatnya yaitu kemampuan berpikir kritis siswa.

\section{Tabel 1.Operasional Variabel}

\begin{tabular}{|c|c|c|}
\hline Variabel & Konsep & Indikator Konsep Analisis \\
\hline $\begin{array}{l}\text { Metode } \\
\text { Problem } \\
\text { Solving } \\
\text { (X) }\end{array}$ & $\begin{array}{l}\text { Menurut Majid (2015: 213) } \\
\text { menyatakan Problem Solving } \\
\text { merupakan pembelajaran berbasis } \\
\text { masalah, yakni pembelajaran yang } \\
\text { berorientasi "learner centered" dan } \\
\text { berpusat pada pemecahan suatu } \\
\text { masalah oleh peserta didik melalui } \\
\text { kerja kelompok }\end{array}$ & $\begin{array}{l}\text { 1. Merumuskan masalah } \\
\text { 2. Menelaah masalah } \\
\text { 3. Merumuskan hipotesis } \\
\text { 4. Mengumpulkan dan } \\
\text { mengelmpokkan data } \\
\text { sebagai bahan pembuktian } \\
\text { hipotesis } \\
\text { 5. Pembuktian hipotesis } \\
\text { 6. Menentukan pilihan } \\
\text { penyelesaian }\end{array}$ \\
\hline $\begin{array}{l}\text { Berpikir } \\
\text { Kritis } \\
\text { (Y) }\end{array}$ & $\begin{array}{l}\text { Berpikir kritis adalah kemampuan } \\
\text { intelektual yang memungkinkan } \\
\text { seseorang untuk terampil dan aktif } \\
\text { dalam hal pemahaman, } \\
\text { pengaplikasian, pensitesisan, serta } \\
\text { pengevaluasian bermacam-macam } \\
\text { informasi yang diakumulasikan dari } \\
\text { berbagai pengamatan, refleksi, } \\
\text { penalaran, komunikasi dan } \\
\text { pengalaman yang dialaminya. } \\
\text { (Liberna, 2012). }\end{array}$ & $\begin{array}{l}\text { 1. } \begin{array}{l}\text { Elementary clarification } \\
\text { (memberikan penjelasan }\end{array} \\
\text { sederhana) } \\
\text { 2. } \begin{array}{l}\text { Basic support (membangun } \\
\text { keterampilan dasar) }\end{array} \\
\text { 3. Inference (menyimpulkan) } \\
\text { 4. Advance classification } \\
\text { (membuat klasifikasi lanjut) } \\
\text { 5. Strategies and tactics } \\
\text { (strategi dan taktik) }\end{array}$ \\
\hline
\end{tabular}

\section{HASIL DAN PEMBAHASAN}

\section{Analisis Data}


Dalam penelitian ini pengujian validitas diujikan pada 35 responden yaitu siswa kelas XI IPS 1 di SMAN 2 Lembang, sehingga diperoleh nilai $r_{\text {tabel }}=0.3338$. Berdasarkan hasil perhitungan dari 20 soal ternyata semua soal memiliki nilai lebih besar bila dibandingkan dengan nilai $r_{\text {tabel }}$. Sehingga dapat disimpulkan bahwa seluruh item soal pilihan ganda yang diuji cobakan telah valid.Nilai alpha dari hasil perhitungan SPSS 21 adalah 0.782 lebih besar dari nilai $r_{\text {tabel }} 0.3338$ maka seluruh item soal pilihan ganda yang diuji cobakan tersebut reliabel. Dari hasil perhitungan dapat di jelaskan bahwa dari 20 soal yang termasuk dalam kategori sukar berjumlah 10 item, soal dalam kategori sedang berjumlah 7 item, dan yang termasuk soal dalam kategori mudah berjumlah 3 item. Berdasarkan perhitungan dapat disimpulkan bahwa seluruh soal instrumen memiliki daya pembeda yang jelek, cukup, dan baik untuk digunakan sebagai instrumen pengukuran pemahaman konsep siswa.

Dalam hal ini data tentang metode pembelajaran problem solving berupa data kuantitatif yang diperoleh dari hasil pretes dan postest. Tes tersebut digunakan untuk mengetahui kemampuan berpikir kritis pada siswa SMAN 2 Lembang. Data yang diperoleh dianalisis untuk mengetahui normalitas, homogenitas, dan uji kesamaan rerata dengan menggunkan program SPSS versi 21.

Tabel 2.Nilai Pretes dan Postes Kemampuan Berpikir Kritis Peserta Didik

\begin{tabular}{|l|c|c|c|c|}
\hline & $\begin{array}{c}\text { Pretes } \\
\text { Eksperimen }\end{array}$ & $\begin{array}{c}\text { Postes } \\
\text { Eksperimen }\end{array}$ & $\begin{array}{c}\text { Pretes } \\
\text { Kontrol }\end{array}$ & $\begin{array}{c}\text { Postes } \\
\text { Kontrol }\end{array}$ \\
\hline N & 36 & 36 & 36 & 36 \\
\hline Min & 25 & 65 & 15 & 50 \\
\hline Max & 45 & 90 & 35 & 80 \\
\hline Mean & 45,15 & 85,35 & 34,31 & 72,55 \\
\hline
\end{tabular}

Dari Tabel 2 dapat disimpulkan bahwa data yang diperoleh dari nilai pretes kelas eksperimen dengan jumlah siswa sebanyak 36 memperoleh nilai minimum 25 dan nilai maximum 45 dengan nilai rata-rata 45,15 dan untuk kelas kontrol dengan jumlah siswa sebanyak 36 memperoleh nilai minimum 15 dan nilai maximum 35 dengan nilai rata-rata 34,31. Sedangkan data yang diperoleh dari nilai postes yaitu nilai kemampuan berpikir kritis ekonomi kelas eksperimen dari 36 peserta didik nilai minimum 65dan nilai maximum 90 memiliki rata-rata 85,35dan nilai kemampuan berpikir kritis ekomoni kelas kontrol dari 36 peserta didik dengan nilai 
minimum 50 dan nilai maximum 80 memiliki rata-rata 72,55sehingga dapat dikatakan bahwa nilai rata-rata kemampuan berpikir ekonomi kelas eksperimen lebih tinggi daripada nilai rata-rata kemampuan berpikir kritis ekonomi kelas kontrol.

\section{Teknik Analisis Data}

\section{Uji Normalitas}

Uji normalitas diberikan kepada kedua kelompok kelas yang diberikan perlakuan berbeda dan diharapkan data yang diperoleh dari hasil penelitian berdistribusi normal. Adapun simpulan hasil uji normalitas, dapat dilihat dari tabel 3.

Tabel3. Hasil Uji Normalitas

\begin{tabular}{|c|c|c|c|}
\hline \multirow{2}{*}{ Kelas } & \multicolumn{3}{|c|}{ Shapiro-Wilk } \\
\cline { 2 - 4 } & Statistic & Df & Sig. \\
\hline Eksperimen & 0.972 & 36 & 0.436 \\
Kontrol & 0.95 & 36 & 0.088 \\
\hline
\end{tabular}

Berdasarkan tabel 3, dapat terlihat bahwa nilai kelompok eksperimen dan untuk kelompok kontrol lebih besar $\alpha=(0.05)$, ini berarti distribusi nilai pada setiap kelas berdistribusi normal.

\section{Uji Homogenitas}

Selanjutnya dilakukan uji homogenitas. Uji homogenitas dimaksudkan untuk menguji apakah data dari masing-masing sampel mempunyai varians yang sama atau tidak. Adapun simpulan hasil uji homogenitas, dapat dilihat dari tabel 4.

Tabel 4. Uji Homogenitas

\begin{tabular}{|c|c|c|c|}
\hline $\begin{array}{c}\text { Levene } \\
\text { Statistic }\end{array}$ & df1 & df2 & Sig. \\
\hline .150 & 1 & 70 & .700 \\
\hline
\end{tabular}

Berdasarkan tabel 4, dapat terlihat bahwa nilai signifikan sebesar 0,700 lebih besar dari 0,05 diperoleh kesimpulan bahwa siswa kelas eksperimen dan kelas kontrol mempunyai data yang homogen.

\section{Uji Hipotesis}

Hipotesis tersebut dirumuskan dalam bentuk hipotesis sebagai berikut: 
$\mathrm{H}_{0}$ : Tidak terdapat peningkatan kemampuan berpikir kritis peserta didik antara kelas yang menggunakan metode pembelajaran problem solving dengan kelas yang menggunakan metode pembelajaran konvensional.

$\mathrm{H}_{1}$ : Terdapat peningkatan kemampuan berpikir kritis peserta didik antara kelas yang menggunakan metode pembelajaran problem solving dengan kelas yang menggunakan metode pembelajaran konvensional.

\begin{tabular}{|c|c|c|c|c|c|c|}
\hline \multicolumn{7}{|c|}{ Tabel5 Uji-T Postes } \\
\hline & & \multicolumn{2}{|c|}{$\begin{array}{l}\text { Levene's } \\
\text { Test for } \\
\text { Equality of } \\
\text { Variances }\end{array}$} & \multicolumn{3}{|c|}{$\begin{array}{l}\text { t-test for Equality of } \\
\text { Means }\end{array}$} \\
\hline & & $\mathrm{F}$ & Sig. & $\mathrm{T}$ & Df & $\begin{array}{l}\text { Sig. (2- } \\
\text { tailed) }\end{array}$ \\
\hline \multirow{2}{*}{$\begin{array}{l}\text { Nilai } \\
\text { Peserta } \\
\text { Didik }\end{array}$} & $\begin{array}{l}\text { Equal } \\
\text { variances } \\
\text { assumed }\end{array}$ & 0.13 & 0.6 & 2.003 & 70 & 0.008 \\
\hline & $\begin{array}{l}\text { Equal } \\
\text { variances } \\
\text { not } \\
\text { assumed }\end{array}$ & & & 2.003 & 43.141 & 0.008 \\
\hline
\end{tabular}

Berdasarkan hasil penelitian, dapat diketahui bahwa penggunaan metode pembelajaran problem solving memiliki pengaruh terhadap kemampuan berpikir kritis ekonomi. Hal ini ditunjukan dengan hasil uji-t diperoleh nilait sebesar 2.003 dengan taraf signifikansi (2-tailed) adalah 0,008, karena nilai kurang dari 0,05 diperoleh kesimpulan bahwa $\mathrm{H}_{0}$ ditolak dan $\mathrm{H}_{1}$ diterima atau terdapat peningkatan kemampuan berpikir kritis peserta didik antara kelas yang menggunakan metode pembelajaran problem solving dengan kelas yang menggunakan metode pembelajaran konvensional. Meningkatnya kemampuan berpikir kritis siswa pada kelas eksperimen di karenakan perubahan metode pembelajaran yang mencakup kegiatan untuk melatih kemampuan berpikir kritis peserta didik.

Metode pembelajaran problem solvingmengajak siswa secara langsung aktif terlibat dalam proses pembelajaran. Melalui metode problem solving, siswa dilatih memecahkan berbagai permasalahan terutama masalah-masalah yang terkait dengan pokok bahasan yang sedang diajarkan. Masalah-masalah tersebut dapat diambil dari masalah-masalah atau isu-isu yang sedang berkembang di masyarakat 
atau masalah-masalah yang terjadi di lingkungan sekolah (Tijayanti, 2014). Metode pembelajaran problem solving adalah metode pembelajaran yang digunakan sebagai alternatif dalam pembelajaran. Kondisi yang diharapkan dengan penerapan metode pembelajaran problem solving yaitu pembelajaran menjadi efektif dan efisien, peserta didik lebih antusias untuk dapat mengerjakan soal-soal agar tujuan pembelajaran dapat tercapai (Rahmawanty, 2017).

Dengan demikian hasil pengolahan analisis data menunjukkan bahwa penerapan metode pembelajaran problem solving dapat meningkatkan kemampuan berpikir kritis peserta didik pada mata pelajaran ekonomi dan lebih baik dari pada penerapan metode pembelajaran konvensional. Hal ini dapat dilihat dari nilai ratarata postest kelas eksperimen yaitu 85,35 sedangkan pada kelas kontrol nilai ratarata postest yaitu 72,55. Selain itu dapat dilihat dari proses pembelajaran yang cenderung baik, karena peserta didik secara aktif mengikuti semua rangkaian kegiatan proses pembelajaran secara aktif dan antusias baik secara kelompok maupun individu.

Karena pada dasarnya siswa mempunyai potensi kemampuan berpikir kritis. Potensi tersebut lebih baik dilatih sejak dini melalui pembelajaran yang mengaharuskan siswanya aktif dan sangat disayangkan jika tidak dapat dikembangkan dengan baik karena jika potensi tersebut tidak diasah dan dikembangkan secara optimal, maka akan tumpul bahkan hilang. Dengan demikian, penerapan metode problem solving dapat melatih kemampuan berpikir kritis peserta didik. Hal ini dapat terlihat dari hasil penilaian kemampuan berpikir kritis peserta didik yang semakin meningkat.

Ciri-ciri seseorang yang memiliki kemampuan berpikir kritis, yaitu mampu menyelesaikan suatu masalah dengan tujuan tertentu, mampu menganalisis dan menggeneralisasikan ide-ide berdasarkan fakta yang ada, serta mampu menarik kesimpulan dan menyelesaikan masalah secara sistematik dengan argumen yang benar. Apabila seseorang hanya mampu menyelesaikan masalah tanpa mengetahui alasan konsep tersebut diterapkan maka ia belum dapat dikatakan memiliki kemampuan berpikir kritis (Setyawati, 2013).

Kemampuan berpikir kritis dan pemecahan masalah mengarah pada kemampuan berpikir secara kritis, lateral, dan sistemik, terutama dalam konteks 
pemecahan masalah. Kemampuan berkomunikasi dan bekerjasama yakni mampu berkomunikasi dan berkolaborasi secara efektif dengan berbagai pihak. Kemampuan mencipta dan membaharui berkaitan dengan mampunya seseorang dalam mengembangkan kreativitas yang dimilikinya untuk menghasilkan berbagai trobosan yang inovatif (BSNP, 2010).

\section{KESIMPULAN}

Berdasarkan hasil analisis data yang diperoleh bahwa nilai kemampuan berpikir kritis ekonomi kelas eksperimen dari 36 peserta didik nilai tertinggi 90 dan nilai terendah 65 memiliki rata-rata 85,35. Sedangkan nilai kemampuan berpikir kritis ekomoni kelas kontrol dari 36 peserta didik dengan nilai tertinggi 80 dan nilai terendah 50 memiliki rata-rata 72,55 sehingga dapat dikatakan bahwa nilai rata-rata kemampuan berpikir ekonomi kelas eksperimen lebih tinggi daripada nilai rata-rata kemampuan berpikir kritis ekonomi kelas kontrol. Dan data dari pengujian hipotesis diperoleh kesimpulan bahwa terdapat peningkatan terhadap kemampuan berpikir kritis siswa yang memperoleh metode pembelajaran problem solving dari pada siswa yang memperoleh pembelajaran konvensional dengan taraf signifikansi (2-tailed) adalah 0,008 .

\section{REFERENSI}

Pendidikan, B. S. N. (2010). Paradigma pendidikan nasional abad XXI. Jakarta: $B S N P$.

Depdiknas. (2003). Undang-Undang RI No. 20 tahun 2003. Tentang Sistem Pendidikan Nasional. Jakarta.

Iskandar, A. ( 2017). Practical Problem Solving. PT Elex Media Komputindo. Jakarta.

Komalasari, K. (2011). Pembelajaran Kontekstual Konsep dan Aplikasi. Refika Aditama. Bandung.

Lambertus. (2009). Pentingnya Melatih Keterampilan Berpikir Kritis Dalam Pembelajaran Matematika Di SD. Forum Pendidikan, 28 (2), 136-142.

Liberna, H. (2012). Peningkatan Kemampuan Berpikir Kritis Matematis Siswa Melalui Penggunaan Metode Improve Pada Materi Sistem Persamaan Linear $\begin{array}{llll}\text { Dua Variabel. } & \text { Formatif, } & 2 & \text { (3), 190-197. }\end{array}$ https://doi.org/10.30998/formatif.v2i3.101.

Majid, Abdul. (2015). Strategi Pembelajaran. Remaja Rosdakarya. Bandung. 
Maryam. S., Setiawati. S., Ekasari, M.F (2008). Buku Ajar Berpikir Kritis dalam Proses Keperawatan. Jakarta: EGC.

Mustaji. (2012). Developing Critical Thinkers (Brookfield). Jossey Bass Publiser. San Fransisco.

Permatasari, R. (2012). Pemecahan Masalah (Penelitian Tindakan Pada Siswa kelas IV SDN Guntur 04 Pagi Setiabudi Jakarta Selatan). Jurnal Pendidikan Dasar, $3(5), 147-154$.

Peter, E. E. (2012). Critical thinking: Essence for teaching mathematics and mathematics problem solving skills. African Journal of Mathematics and Computer Science Research, 5 (3), 39-43. https://doi.org/academicjournals.org/AJMCSR.

Prayitno, L. L., Sulistyawati, I., \& Wardani, S. (2016). Profil Kemampuan Berpikir Kritis Siswa SD Di Kecamatan Bulak. JPDN (Jurnal Pendidikan Dasar Nusanatara), 1(2), 67-74.

Rahmawanty, N. (2017). Pengaruh Metode Pembelajaran Problem Solving Terhadap Kemampuan Berpikir Kritis Matematika. Jurnal Kajian Pendidikan Matematika, 2(2), 201-210. https://doi.org/10.1007/XXXXXX-XX-0000-00.

Rohaumah, C. (2018). Pengaruh Metode Pembelajaran Discovery Learning Terhadap Kemampuan Bepikir Kritis. Jurnal Gammath, 3(1).

Setyawati, R. D. (2013). Pengembangan Perangkat Pembelajaran Matematika Model Problem Based Learning Berorientasi Enterpreneurship dan Berbantuan CD Interaktif. In Prosiding Seminar Nasional Matematika.

Shoimin, A.(2014).68 Model Pembelajaran Inovatif dalam Kurikulum 2013.Ar-Ruzz Media.Yogyakarta.

Tijayanti, I\& Marzuki. (2014). Keefektifan Metode Problem Solving dalam Pembelajaran Pkn untuk Pengembangan Kemampuan Berpikir Kritis dan Sikap Nasionalisme di SMA Negeri 1 Suela Lombok Timur. Jurnal IlmuIlmu Sosial, 11(2), 173-182.

U. Setyorini, S.E. Sukiswo, B. S. (2011). Penerapan Model Problem Based Learning Untuk Meningkatkan Kemampuan Berpikir Kritis Siswa Kelas V Sd. Jurnal Pendidikan Fisika Indonesia, $7, \quad 52-56$. https://doi.org/http://journal.unnes.ac.id.

Wena, M. (2011). Strategi Pembelajaran Inovatif Kontemporer. Bumi Aksara. Jakarta.

Wijayanti, T. F. (2016). Potensi Model Pembelajaran Problem Solving disertai Argument Mapping untuk Memberdayakan Berpikir Kritis. Prosiding Seminar Nasional Pendidikan, 1 (1). 